\title{
Oxygen-Related Prostaglandin Synthesis in Ductus Arteriosus and Other Vascular Cells
}

\author{
MARLENE RABINOVITCH, NANCY BOUDREAU, GEORGE VELLA, FLAVIO COCEANI, AND \\ PETER M. OLLEY \\ Divisions of Cardiology, Pathology and Neurosciences, Research Institute, The Hospital for Sick Children and \\ the Departments of Pediatrics, Pathology and Physiology, University of Toronto,
}

Toronto, Ontario, Canada M5G1X8

\begin{abstract}
We compared oxygen-related prostaglandin synthesis in fetal lamb ductus arteriosus (DA) pulmonary artery (PA) and aorta endothelial and smooth muscle cells. We measured basal synthesis of 6-keto-PGF $1 \alpha$ and PGE the response to calcium ionophore (A23187), a nonspecific stimulus of prostaglandin production, as well as the response to oxygen, a perinatal stimulus, monitoring both the effects of hyperoxia $\left(95 \% \mathrm{O}_{2}\right)$ and hypoxia $\left(2 \% \mathrm{O}_{2}\right)$. In addition, we established whether differences observed in fetal lamb PA cells related to oxygen tension were also observed in newborn central and microvessel PA cells. Our results indicate that $\mathrm{DA}$ endothelial cells increase 6-keto$\mathrm{PGF}_{1 \alpha}$ in response to ionophore $(p<0.05)$. With hyperoxia, DA endothelial cells increase $\mathrm{PGE}_{2}$ synthesis and DA smooth muscle cells increase 6-keto-PGF ${ }_{1 \alpha}(p<0.05$ and 0.02 , respectively). Aorta smooth muscle cells increase 6-keto-PGF $1 \alpha$ in response to ionophore and hyperoxia ( $p$ $<0.003$ and 0.05 , respectively). PA endothelial and smooth muscle cells have higher levels of basal prostaglandin synthesis when compared with DA and aorta. In response to ionophore, increased 6-keto-PGF ${ }_{1 \alpha}$ is observed in both PA endothelial and smooth muscle cells $(p<0.02$ and 0.0004, respectively), and $P G E_{2}$ is increased in $P A$ smooth muscle cells $(p<0.003)$. Hypoxia, however, decreases PA smooth muscle production of both 6-keto-PGF ${ }_{1 \alpha}$ and PGE $_{2}$ $(p<0.02$ and 0.01 , respectively). Similar observations were made in newborn lamb central and microvessel PA cells. Thus, the hyperoxia-induced increase in prostaglandin synthesis in DA (endothelium and smooth muscle) and aorta (smooth muscle) and the hypoxia-induced decrease in prostaglandin synthesis in PA (smooth muscle) seem to be phenotypic properties of the cells in culture. (Pediatr. Res 26: 330-335, 1989)
\end{abstract}

\section{Abbreviations}

DA, ductus arteriosus

Ao, aorta

PA, pulmonary artery

DPBS, Dulbecco's PBS

Normal closure of the DA is dependent upon two processes, the prenatal development of intimal cushions (1) and the post-

Received January 18, 1989; accepted May 25, 1989.

Correspondence and reprints Marlene Rabinovitch, M.D., Department of Cardiology, The Hospital for Sick Children, 555 University Avenue, Toronto, Ontario, Canada M5G 1 X8.

Supported by the Medical Research Council of Canada Grant MT 857. M.R is a Research Associate of the Heart and Stroke Foundation of Ontario. natal constriction of the vessel wall (2). The identity of the constrictor remains unknown, although its formation from a cytochrome P-450-dependent monooxygenase pathway is likely (3). We have previously established and characterized endothelial and smooth muscle cell cultures from the DA (4). When compared with cells from the Ao and PA, DA cells are similar in appearance and growth, but show both qualitative and quantitative differences in protein synthesis (4). The purpose of this study was to establish whether oxygen-induced production of prostaglandins is also different in DA cells. The results of these experiments could therefore serve as the background for future work related to the mechanism of oxygen-induced release of vasoactive substances. We compared basal DA endothelial and smooth muscle synthesis of $\mathrm{PGE}_{2}$ and 6-keto-PGF ${ }_{1 \alpha}$, the stable metabolite of prostacyclin, with that of PA and Ao cells, as well as the response to a nonspecific stimulus, the calcium ionophore (A23187), and a perinatal stimulus, oxygen. We also assessed whether changes in prostaglandin production in the fetal PA were also reflected in newborn central and microvessel PA cells.

\section{MATERIALS AND METHODS}

Materials. DPBS, medium 199 (contains $5 \mathrm{mM} \mathrm{CaCl}_{2}$ ) with $25 \mathrm{mM}$ HEPES buffer and glutamine, antibiotic-antimycotic solution (penicillin, streptomycin, fungizone), and FCS were purchased from GIBCO, Burlington, Ontario. Culture dishes (35 $\mathrm{mm}$ ) were Nunclon, from Nunc, Denmark, flasks and 15-mL tubes were from Costar, Cambridge, MA. Microcarrier beads (Cytodex III), were from Pharmacia, Uppsala, Sweden. Antibody to human factor VIII was obtained from Behring Diagnostics Inc. Branchburg, NJ and ovine factor VIII antibody was kindly supplied by Dr. M. Andrew, McMaster University, Hamilton, Ontario, Canada. Angiotensin converting enzyme substrate, $\left[{ }^{3} \mathrm{H}\right]$ benzoyl-phe-ala-pro came from Ventrex Laboratories, Portland, ME. Radiolabeled compounds, $\left[5,6,8,9,11,12,14,15,{ }^{-}{ }^{3} \mathrm{H}(\mathrm{N})\right]$ arachidonic acid, $(83.6 \mathrm{Ci} / \mathrm{mmol})$ and $\left[5,6,8,11,12,14,15-{ }^{3} \mathrm{H}(\mathrm{N})\right]$ $\mathrm{PGE}_{2}(185 \mathrm{Ci} / \mathrm{mmol})$ and $\left[5,8,9,11,12,14,15,{ }^{3} \mathrm{H}(\mathrm{N})\right]$ 6-keto$\mathrm{PGF}_{1 \alpha}(157 \mathrm{Ci} / \mathrm{mmol})$ were obtained from New England Nuclear, Boston, MA. Unlabeled thromboxane $\mathbf{B}_{2}$, prostaglandin $\mathrm{D}_{2}, \mathrm{PGF}_{2 \alpha}$, were from Upjohn, Kalamazoo, MI and 5-HETE and 15-HETE, from Biomol, Philadelphia, PA. Calcium ionophore A23187 was obtained from Sigma Chemical Co., St. Louis, MO and scintillation fluid (ACS) from Amersham, Oakville, Ontario, Canada.

Culturing and characterizing vascular cells. Fetal Rambouillet lambs were delivered by cesarean section on d 135-138 of gestation (term $145 \mathrm{~d}$ ), and the great vessels were removed as previously described $(3,4)$. The DA, PA, and Ao were separated, opened, and rinsed in DPBS supplemented with $\mathrm{Ca}^{2+}$ and $\mathrm{Mg}^{2+}$ ( 2.5 and $4.1 \mathrm{mM}$, respectively) and $3 \%$ antibiotic-antimycotic solution. Endothelial cells were subsequently harvested by scrap- 
ing the luminal surface of the vessel with a no. 11 scalpel blade $(4,5)$ and immersing the blade in a $35-\mathrm{mm}$ culture dish containing medium 199 (contains $5 \mathrm{mM} \mathrm{CaCl}$ ), 20\% FCS, and $1 \%$ antibiotic-antimycotic solution. The culture medium was not supplemented with growth factors. Cells were then grown to confluence and passaged nonenzymatically 1:2. Growth rates and attachment efficiencies have been previously published (4). Differences were apparent comparing endothelial and smooth muscle cells, but not in relation to vascular site, i.e. DA, PA, or Ao.

After removing the adventitia from the vessels, explants of the muscular media were cultured in $25-\mathrm{mL}$ flasks using the same medium as the endothelial cells, but with $10 \%$ FCS added. Smooth muscle cells were propagated from the explants (6) and also passaged 1:2 nonenzymatically at confluence.

Rambouillet lambs, 3-5 days of age, were used as the source of newborn PA central and microvessel endothelial and smooth muscle cells. Microvessel endothelial cells were harvested by a previously described perfusion technique using microcarrier beads, $40-140 \mu \mathrm{m}(7,8)$. The cells that attached to the beads were largely endothelial, but some smooth muscle cells were also present that formed colonies that were later subcultured. Endothelial and smooth muscle cells from the central PA were harvested and cultured following the technique described for fetal cells.

Endothelial cells in culture were characterized by phase contrast light microscopy as forming a typical "cobblestone," contact inhibited monolayer $(4,5,7)$. At passage 2 , positive immunofluorescence was demonstrated using both a human and ovine antibody to factor VIII $(4,5)$. Furthermore, levels of angiotensin converting enzyme activity (9) were accordant with published values (4). Newborn central PA endothelial cells were similar to both newborn microvessel PA and fetal central PA cells in terms of converting enzyme activity, but they took approximately 1 mo longer to reach confluence at passage 3 . Smooth muscle cells were characterized by the "hills and valleys" phenotype on phase contrast light microscopy $(4,10)$ and by positive immunofluorescence (11) using a smooth muscle specific actin antibody kindly supplied by Dr. A. Gown, University of Washington, Seattle, WA.

Measurement of prostaglandin synthesis. Confluent endothelial and smooth muscle cells from fetal DA, PA, and Ao at passage 3 were used for measurement of prostaglandin synthesis. To each $25-\mathrm{mL}$ flask, containing approximately $1.2 \times 10^{6}$ cells, fresh serum-free medium 199 with $1 \mu \mathrm{Ci}\left[{ }^{3} \mathrm{H}\right]$ arachidonic acid was added (final volume $4 \mathrm{~mL}$ ) and incubation was continued for $24 \mathrm{~h}$ at $37^{\circ} \mathrm{C}$. The medium was then removed, cells were washed twice with $5 \mathrm{~mL}$ DPBS and then $4 \mathrm{~mL}$ of fresh serum free medium 199 were added. Prostaglandin production was assessed over a $1-\mathrm{h}$ period under one of the following conditions 1) room air, 2) room air plus calcium ionophore A23187 (final concentration $5 \mu \mathrm{M}), 3)$ hypoxia $\left(2 \% \mathrm{O}_{2}, 5 \% \mathrm{CO}_{2}, 93 \% \mathrm{~N}_{2}\right)$ and 4) hyperoxia $\left(95 \% \mathrm{O}_{2}, 5 \% \mathrm{CO}_{2}\right)$. To maintain the ambient oxygen environment, the cap of the flask was replaced with a rubber stopper pierced by two 18-gauge needles attached to 3way stopcocks. One needle was attached to silastic tubing to bubble the various gas mixtures through the medium at $1 \mathrm{~L} / \mathrm{min}$ for $5 \mathrm{~min}$; the second needle was attached to a stopcock which remained open to allow gas to flow out of the flask over this time period, and then both stopcocks were closed for the remainder of the incubation time. One $\mathrm{h}$ later, the first stopcock with attached silastic tubing was open for withdrawal of $3.5 \mathrm{~mL}$ of culture medium to measure prostaglandins by HPLC and the remainder, $0.5 \mathrm{~mL}$, was removed to measure the $\mathrm{PO}_{2}$ (Corning Blood Gas Analyzer, Corning Glass Works, Medfield, MA). $\mathrm{PO}_{2}$ values were $24-42 \mathrm{~mm} \mathrm{Hg}$, and $517-620 \mathrm{~mm} \mathrm{Hg}$, respectively, in 2 and $95 \%$ oxygen for all incubations. Room air values were only verified in a few samples and found to be within the expected 120-130 $\mathrm{mm} \mathrm{Hg} \mathrm{Po}_{2}$ range.

The newborn central and microvessel PA cells were obtained from at least three different harvests but each flask was used as its own control. All cells were incubated with $1 \mu \mathrm{Ci}\left[{ }^{3} \mathrm{H}\right]$ arachidonic acid as described above, and prostaglandin synthesis was assessed during $1 \mathrm{~h}$ of exposure to room air. Fresh serum-free medium was added to the flask and repeat assessment was made during one hour of hypoxia $\left(2 \% \mathrm{O}_{2}, 5 \% \mathrm{CO}_{2}, 93 \% \mathrm{~N}_{2}\right)$. Then, $0.5 \mathrm{~h}$ equilibration in room air intervened after which, fresh serum-free medium with calcium ionophore A23187 (final concentration $5 \mu \mathrm{M}$ ) was added. Prostaglandin synthesis was reassessed in room air only to ascertain that, despite the change in precursor pool, the cells could respond to a prostaglandin-producing stimulus.

In all experiments, cells were checked after the exposure to ionophore, hypoxia, or hyperoxia to verify that they had maintained an intact cobblestone phenotype and had no signs of detachment or injury from the 5 -min bubbling. None was observed. The culture medium was then removed, and the cells from each flask were subsequently scraped in DPBS, aspirated up and down in a syringe via an 18-gauge needle to break up the clumps and counted (model $\mathrm{HZ}$ counter, Coutler Electronics, Hialeah, FL) so that results could be referred quantitatively to the constituent cells. The culture medium removed was acidified with $1 \mathrm{~N} \mathrm{HCl}$ to $\mathrm{pH} 3$ and passed through a $\mathrm{C}_{18}$ Sep-Pak followed by $2 \times 5 \mathrm{~mL}$ DPBS washes. The cartridges were then rinsed with $6 \mathrm{~mL} \mathrm{H}_{2} \mathrm{O}, 6 \mathrm{~mL}$ hexane and the prostaglandins were eluted off the Sep-Pak with $12 \mathrm{~mL}$ acetone. Recovery was $86-90 \%$. The acetone fraction was evaporated under a stream of $\mathrm{N}_{2}$ and samples were reconstituted in $250 \mu \mathrm{L}$ acetonitrile.

Prostaglandins were resolved using an HPLC system from Waters, Milford, MA which included two model 510 pumps and a $\mathrm{C}_{18}$ Nova-Pak column $(15.0 \times 3.5 \mathrm{~cm})$. A flow rate of $1.5 \mathrm{~mL} /$ min with an isocratic gradient system of $0.1 \% \mathrm{H}_{3} \mathrm{PO}_{4} / \mathrm{CH}_{3} \mathrm{CN}$ (3:1 by vol) ( $\mathrm{pH} 3.5$ ) increasing linearly to $100 \% \mathrm{CH}_{3} \mathrm{CN}$ over $18 \mathrm{~min}$ was used. Radioactivity was monitored using a Berthold LB505 detector and LB 5034 splitter/mixer (Berthold, Wildbad, West Germany, distributed by Labserco, Oakville, Ontario, Canada) interfaced to a Waters System module with a Digital 350 Professional Computer (Waters, Milford, MA). At the same time, 1 -min fractions of eluate were collected and mixed with $3 \mathrm{~mL}$ ACS scintillation fluid and counted on a 1219 Rackbeta Spectral liquid scintillation counter (LKB, Washington, DC). Radiolabeled standards of 6-keto-PGF $\mathrm{PG}_{1 \alpha}, \mathrm{PGE}_{2}$, and arachidonic acid had retention times of $5.5,9.4$, and $18 \mathrm{~min}$, respectively. Retention times of unlabeled standards detected at $195 \mathrm{~nm}$ using a Waters model 490 multiwavelength U.V. detector, were as follows: $\mathrm{PGD}_{2}, 10.5 \mathrm{~min}$, thromboxane $\mathrm{B}_{2}, 7 \mathrm{~min}, \mathrm{PGF}_{2 \alpha}, 8 \mathrm{~min}$, hydroxyacids, (5-HETE and 15-HETE), 13 and $18.8 \mathrm{~min}$, respectively. Recovery of the radiolabeled standards was $99 \%$. Inasmuch as the monohydroxyacid retention times coincided with the shoulder of the arachidonic acid peak, any small amount of HETE compound, could not be resolved by our system.

In a few experiments in room air sampling endothelial and smooth muscle cells from the DA, Ao, and PA, we monitored the amount of radiolabeled arachidonic acid that remained incorporated in the cells and the proportion released into the fresh medium. Of the latter, we assessed how much was arachidonic acid relative to prostaglandins. Approximately $50 \%$ of the added tracer remained incorporated in the cells and $15 \%$ was released into the medium after the $1-\mathrm{h}$ experimental period. Of the latter, approximately $95 \%$ was arachidonic acid, $3 \% \mathrm{PGE}_{2}$ and $2 \% 6-$ keto-PGF ${ }_{1 \alpha}$.

To rule out any interference from catabolism with the measured levels of prostanoids, the following additional studies were carried out. Flasks with confluent (passage 3) PA, Ao, and DA endothelial and smooth muscle cells were incubated in serumfree medium 199 for $24 \mathrm{~h}$ at $37^{\circ} \mathrm{C}$ to simulate the conditions of the previous experiments. The incubation medium was then replaced with $2 \mathrm{~mL}$ of fresh medium to which $1 \mu \mathrm{Ci}\left[{ }^{3} \mathrm{H}\right] \mathrm{PGE}_{2}$ had been added, and the cells were incubated for a further $1 \mathrm{~h}$ at $37^{\circ} \mathrm{C}$. The medium was removed, cells washed twice with $2 \mathrm{~mL}$ 
DPBS, and washes pooled. Combined medium and washes were passed over a $\mathrm{C}_{18}$ Sep-Pak and acetone was added to bring the final volume to $12 \mathrm{~mL}$. The samples were dried under $\mathrm{N}_{2}$ and reconstituted into $0.3 \mathrm{~mL}$ acetone: aliquots of the unknown (50 $\mu \mathrm{L}$ ) and standards were applied to silica-coated thin-layer chromatography plates and samples were developed for $1.5 \mathrm{~h}$ in chloroform:methanol:acetic acid:water (90:9:1:0.65 by vol). The portion of the plates containing the standards was then sprayed with phosphomolybdic acid (10\% in ethanol), whereas radioactivity in the unknown was determined using a Berthold scanner (model LB2722-2). No evidence of catabolism was found because $92-99 \%$ of added radioactivity was recovered and migrated on thin-layer chromatography as a single peak with the same mobility as the $\mathrm{PGE}_{2}$ standard.

Analysis of data. Comparisons of data were based upon values obtained from four flasks for each cell type (e.g. PA smooth muscle). Cells were derived from at least two different harvests. Because of the variability in the distribution of the data, logarithmic transformation was performed and then a one-way analysis of variance was used to determine whether, for baseline endothelial or smooth muscle values of 6-keto-PGF ${ }_{1 \alpha}$ or $\mathrm{PGE}_{2}$, there was a difference related to the origin of the cells and whether for a given origin, there were differences related to the experimental condition (e.g. hypoxia, hyperoxia, or ionophore). An $F$ test (control versus stimulus) was then calculated (12) and a more stringent Tukey's test was also used to establish for each cell type, whether a specific expermental condition, produced a significant difference. In newborn PA central cells and in those derived from microvessels, the paired Student's $t$ test was used to compare prostaglandin synthesis values during normoxia with those obtained during hypoxia. All values are given as mean \pm $\mathrm{SE}$, and differences are considered significant with $p<0.05$.

\section{RESULTS}

In the DA, there were no significant changes in endothelial or smooth muscle prostaglandin synthesis with hypoxia (Figs. 1 and 2). Hyperoxia, however, increased both endothelial $\mathrm{PGE}_{2}(p<$ $0.05, F$ test) (Fig. 1) and smooth muscle 6-keto-PGF ${ }_{1 \alpha}(p<0.02$, $F$ test, and $<0.05$, Tukey's test) (Fig. 2). In addition, there was a trend toward increased endothelial 6-keto-PGF ${ }_{1 \alpha}(p=0.06, F$ test) (Fig. 1). DA endothelial cells responded to calcium ionophore with increased 6-keto-PGF ${ }_{1 \alpha}$ synthesis $(p<0.05, F$ test) (Fig. 1), but in DA smooth muscle cells (Fig. 2) only a trend toward an increase in $\mathrm{PGE}_{2}$ was apparent.

In the Ao, as in the DA, there was no significant change in endothelial or smooth muscle prostaglandin synthesis with hypoxia. Hyperoxia did not significantly alter Ao endothelial prostaglandin synthesis, but did increase Ao smooth muscle 6-keto$\mathrm{PGF}_{1 \alpha}(p<0.04, F$ test) (Fig. 2). In contrast to the DA, Ao smooth muscle cells, rather then endothelial cells responded to calcium ionophore with increased 6-keto-PGF - $_{1 \alpha}(p<0.0025, F$ test, $<0.05$, Tukey's test).

Basal levels of prostaglandin synthesis were highest in cells from the PA. Endothelial cells from the PA produced more 6keto-PGF $\mathrm{PG}_{1 \alpha}$ than those from either Ao $(p<0.05)$ or DA $(p<$ $0.025)$ and more $\mathrm{PGE}_{2}$ than DA cells $(p<0.025)$ (Fig. 1$)$. Smooth muscle cells from the PA produced more 6-keto-PGF ${ }_{1 \alpha}$ than those from the DA $(0<0.025)$ (Fig. 2). PA endothelial prostaglandin synthesis during hypoxia was not significantly different from that observed in room air (Fig. 1) but PA smooth muscle cells showed a significant decrease in 6-keto-PGF ${ }_{1 \alpha}(p<$ $0.02, F$ test, $<0.01$, Tukey's test $)$ and $\mathrm{PGE}_{2}(p<0.01, F$ test, $<0.05$, Tukey's test) (Fig. 2). In further contrast to DA and Ao cells, hyperoxia did not significantly alter PA endothelial or smooth muscle prostaglandin synthesis. In response to stimulation with calcium ionophore, $6-\mathrm{keto}^{-\mathrm{PGF}_{1 \alpha}}$ was increased in both PA endothelial and smooth muscle cells $(p<0.02$ and $<0.0004$, respectively, $F$ test) (Figs. 1 and 2 ), and $\mathrm{PGE}_{2}$ was increased in smooth muscle cells $(p<0.003, F$ test, $<0.05$, Tukey's test) (Fig. 2).
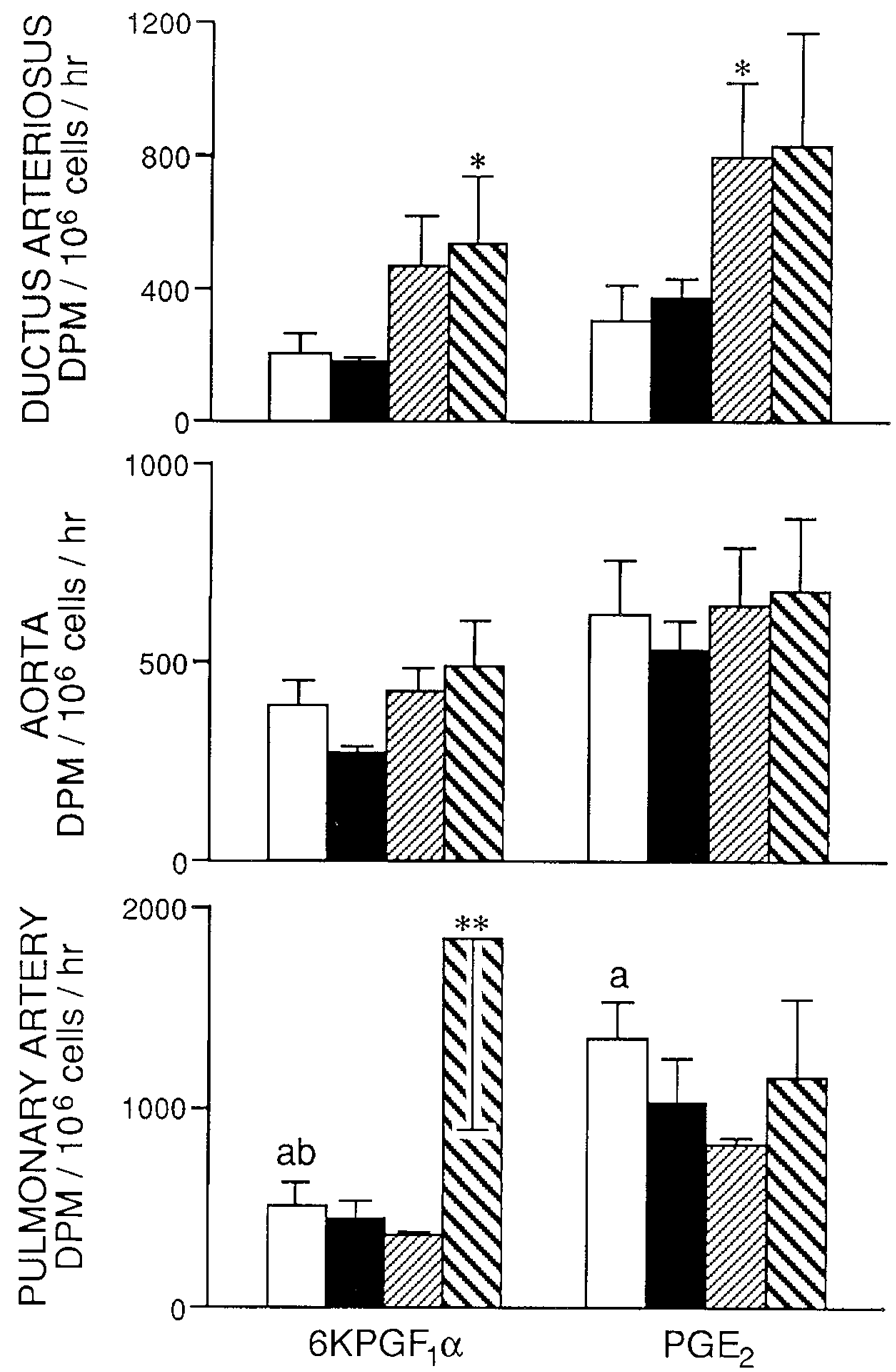

Fig. 1. Fetal endothelial prostaglandin synthesis. A histogram showing 6-keto-PGF $\mathrm{P}_{1 \alpha}$ and $\mathrm{PGE}_{2}$ synthesis during room air $\square$, hypoxia (2\% $\left.\mathrm{O}_{2}\right) \square$, hyperoxia $\left(95 \% \mathrm{O}_{2}\right)$, and stimulation with calcium ionophore, A23187 $\mathbb{\mathbb { N }}\left({ }^{*} p<0.05,{ }^{* *} p<0.02, \mathrm{~F}\right.$ test $) . a$, differs from DA $(p<0.025)$ and $b$, differs from Ao $(p<0.05)$.

As was observed in fetal PA smooth muscle cells, newborn central PA smooth muscle cells also showed decreased production of 6-keto-PGF ${ }_{1 \alpha}$ during hypoxia $(p<0.01)$, and both central and microvessel $\mathrm{PA}$ smooth muscle cells had reduced $\mathrm{PGE}_{2}$ synthesis ( $p<0.05$ and 0.01 , respectively) (Fig. 3 ). The hypoxic stimulus had not interfered with prostaglandin synthesis by damaging the cells in that they subsequently responded to stimulation with ionophore (Fig. 3).

Thus the newborn PA cells responded in a similar manner to hypoxic stimulation despite some differences when compared with fetal cells in baseline prostaglandin synthesis. Fetal PA endothelial cells produced more 6-keto-PGF $\mathrm{PG}_{1 \alpha}$ than newborn central PA endothelial cells, and fetal PA smooth muscle cells produced more 6-keto-PGF $\mathrm{I}_{\alpha}$ than newborn microvessel PA cells ( $p<0.01$ for both comparisons). Newborn central PA smooth muscle cells had higher rates of 6-keto- $\mathrm{PGF}_{1 \alpha}$ synthesis than newborn microvessel PA cells $(p<0.05$, Fig. 3 ).

\section{DISCUSSION}

Prostaglandin synthesis related to vascular site. In this study, we investigated whether cultured endothelial and smooth muscle cells from the fetal DA, PA, and Ao show differences in prostaglandin synthesis related to site and exposure to high versus low 

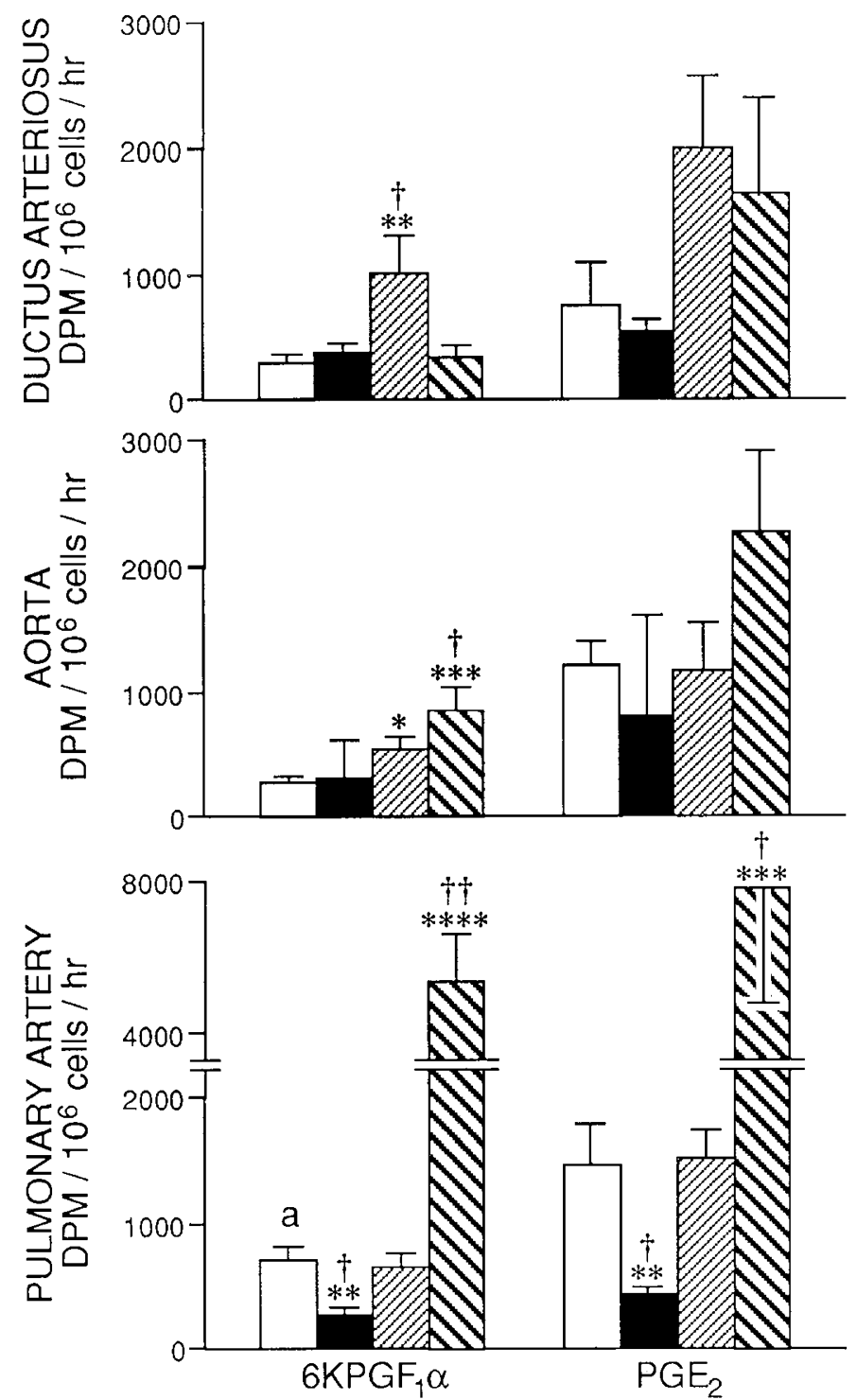

Fig. 2. Fetal smooth muscle prostaglandin synthesis. A histogram showing 6-keto-PGF ${ }_{1 \alpha}$ and $\mathrm{PGE}_{2}$ synthesis in ductus arteriosus, aorta and pulmonary artery smooth muscle cells during room air $\square$, hypoxia $\left(2 \% \mathrm{O}_{2}\right)$, hyperoxia $\left(95 \% \mathrm{O}_{2}\right)$, and stimulation with calcium ionophore, A23187 $\left({ }^{*} p<0.05\right.$ or $0.04,{ }^{* *} p<0.02$ or 0.01$){ }^{* * *} p<0.003$ and $* * * * p<0.0004, \mathrm{~F}$ test $\dagger p<0.05, \dagger \dagger p<0.01$, Tukeys test. $a$, differs from DA $(p<0.025)$.

ambient oxygen. We found that endothelial and smooth muscle cells from all three vascular sites synthesize prostaglandins. Moreover, the amounts recovered are a reflection of synthetic activity in individual cells because no catabolism was evident in our system. We have thus extended studies of other investigators by showing that vascular endothelial and smooth muscle cells not only synthesize prostaglandins (13-15), but also exhibit peculiar features reflecting their origin.

In general, the levels of $\mathrm{PGE}_{2}$ detected were similar or higher than those of 6-keto-PGF ${ }_{1 \alpha}$. Although this has been described in smooth muscle cells, previous reports indicate that cultured endothelial cells produce higher levels of 6 -keto-PGF $\mathrm{PG}_{1 \alpha}$ than $\mathrm{PGE}_{2}$ (13). The conditions we used, i.e. $1 \mathrm{~h}$ serum free, have not however, been previously studied. In other experiments in our laboratory in passage 3 neonatal PA endothelial cells, prostaglandins were assayed after $24 \mathrm{~h}$ in low mitogen serum replacement (Sigma) rather than serum-free medium, and higher levels of 6keto-PGF ${ }_{\mathrm{l} \alpha}$ than $\mathrm{PGE}_{2}$ were measured (16).

A drawback in the interpretation of our results may be the fact that the fetal cells were maintained and propagated in normoxia and this would not reproduce the fetal hypoxic environment. Previous studies by Benitz et al. (17), however, have shown that PA smooth muscle cells do not grow well in a hypoxic environment, so this was a necessary limitation. Despite the fact that they were cultured and passaged in normoxia, fetal cells were initially adapted to low oxygen and for this reason may be phenotypically different. We have established in a previous study that there are qualitative and quantitative differences in protein synthesis in DA cells compared with those from the Ao or PA (4) indicating that they maintain a distinct phenotype in culture. Moreover, studies by Mecham et al. (18) have shown that cells harvested from chronically hypoxic calves, but cultured in room air do indeed maintain phenotypic characteristics related to their altered functions in vivo (19). This is true despite the fact that in vivo vascular abnormalities regress when the calves are removed from the hypoxic environment (19).

We were surprised that DA smooth muscle and Ao endothelial cells did not show an increase in 6-keto-PGF ${ }_{1 \alpha}$ and/or $\mathrm{PGE}_{2}$ synthesis in response to the calcium ionophore because this is a nonspecific stimulus that activates calcium-dependent phopholipase $\mathrm{A}_{2}$. We can only speculate that the lack of responsivity especially of fetal DA smooth muscle and Ao endothelial cells is a feature peculiar to these cells, related perhaps to the accessibility and state of activation of the enzyme.

In previous studies, few differences in metabolic functions have been found when comparing endothelial or smooth muscle cells from different vascular sites (20-22), although arterial endothelial cell synthesis of prostaglandins is generally found to be higher than that of veins (15). In other studies, calcium ionophore was found to be a stimulus of vascular prostaglandin production regardless of site of origin (21). No specific differences were found when comparing bovine PA with Ao. The higher prostaglandin synthesis in PA compared with Ao or DA cells which we observed may reflect the fact that we used fetal cells. Because fetal vessels produce five times more prostacyclin than those of the adult animal, small differences may more readily be apparent (23). Alternatively, the difference may reflect the fact that the cells were harvested and passaged nonenzymatically and, therefore, may have retained characteristics more reflective of their vascular site of origin. Forstermann et al. (24) found that the intact rabbit pulmonary artery produced comparatively higher levels of prostaglandins than the aorta.

Mechanism of hyperoxia-induced $D A$ prostaglandin synthesis. Both in the studies of Coceani et al. (25) and Clyman et al. (26) the response of the isolated DA vessel to hyperoxia consisted of increased $\mathrm{PGE}_{2}$ synthesis. In the study by Coceani et al. (25) increased $\mathrm{PGE}_{2}$ was observed in $\mathrm{DA}$ specimens lacking both intima and adventitia, suggesting that the smooth muscle cells of the media were also an important source. Although 6-ketoPGF $_{1 \alpha}$ was not measured, it could be anticipated that it was also increased. Thus the increased DA endothelial and smooth muscle prostaglandin synthesis observed in cultured cells appears to reflect a property also apparent in intact vessels.

Using time-lapse cinematography, we have demonstrated that DA smooth muscle cells, despite increased production of dilator prostaglandins, do indeed appear to contract during exposure to hyperoxia (Rabinovitch $\mathbf{M}$, unpublished observations), and we are in the process of trying to adapt our system so that we can make further functional measurements, e.g. a measurement of calcium uptake. Because this feature is similar to the DA constriction with hyperoxia observed in whole tissue (4), it appears that the increase in prostaglandin synthesis apparent both in whole tissue and in cell culture may serve to counteract the full effect of an as yet unknown vasoconstrictor (3). Our HPLC system would not be expected to detect the cytochrome P-450dependent metabolite that constricts the vessel because it is likely not an eicosanoid (3).

Whereas we showed an increase in Ao smooth muscle prostacyclin synthesis during hyperoxia, previous studies by other 

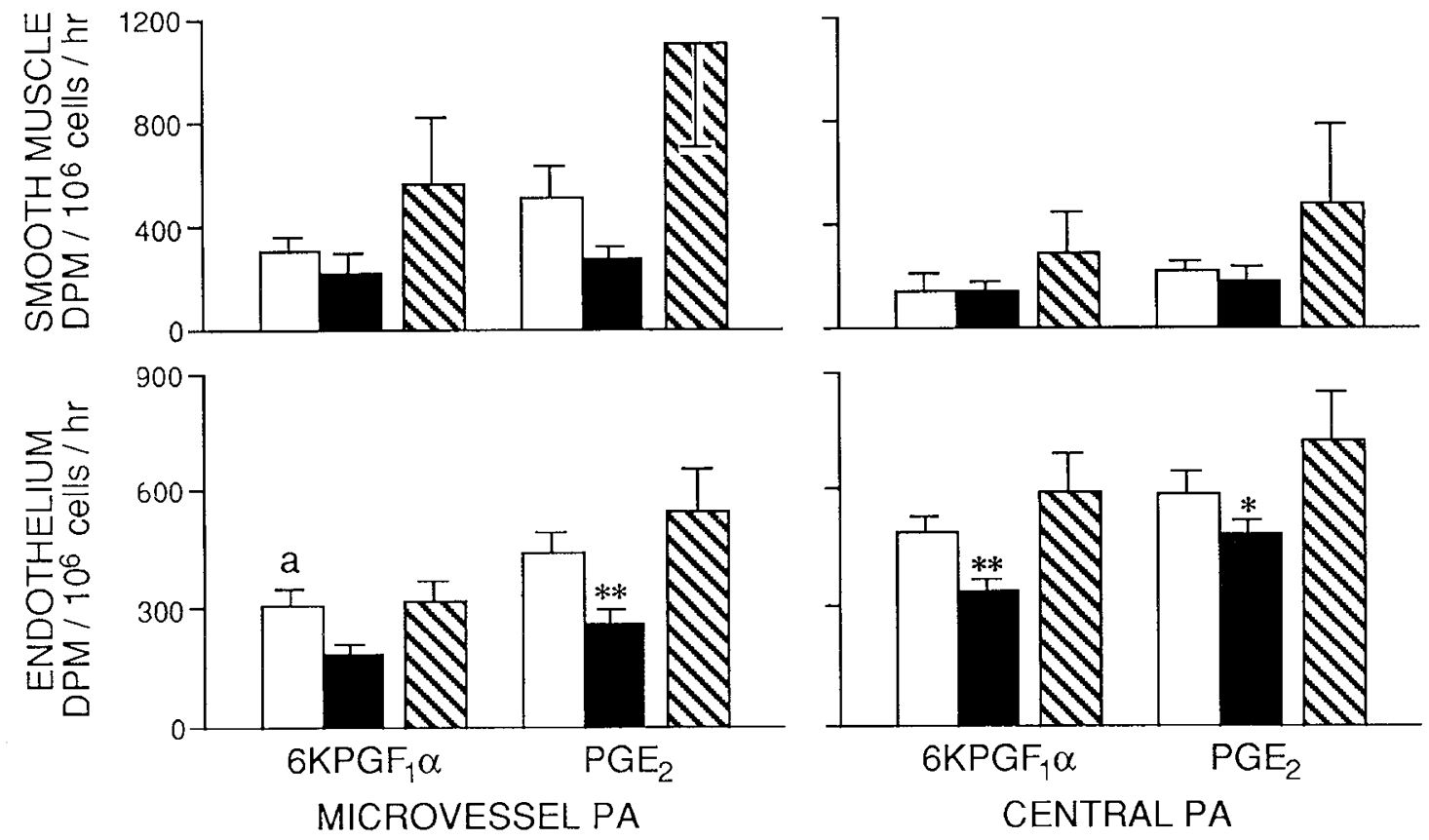

Fig. 3. Newborn pulmonary artery central and microvessel endothelial and smooth muscle prostaglandin synthesis. Histograms showing prostaglandin synthesis of newborn endothelial and smooth muscle cells from central pulmonary artery and pulmonary artery microvessels in room air $\square$, and during hypoxia $\left(2 \% \mathrm{O}_{2}\right)$. The response to ionophore after $0.5 \mathrm{~h}$ equilibration in room air is then shown $\left({ }^{*} p<0.05\right.$ and ${ }^{* *} p<0.01$ paired $t$ test). $a$, differs from central PA $(p<0.05)$.

investigators (27) have observed an increase in Ao endothelial cells, but only after an exposure period much longer than the one we used.

Decreased prostaglandin synthesis in PA smooth muscle cells during hypoxia. The normal level of $\mathrm{PO}_{2}$ in the fetal PA (28) is lower than the one attained in vitro with the $2 \%$ oxygen mixture. The latter would, however, be considered hypoxic for neonatal animals. We chose $2 \%$ oxygen for all our studies because that particular tension represented a relative change from the conditions under which cells had been harvested and propagated.

Synthesis of $\mathrm{PGE}_{2}$ during hypoxia had not been assessed before in cell culture, whole tissue, or isolated lungs. $\mathrm{PGE}_{2}$ is a dilator of the pulmonary vascular bed in newborn goats (29). Thus, the decrease in $\mathrm{PGE}_{2}$ and, even more significant functionally, the decrease in prostacyclin production in PA smooth muscle cells during hypoxic exposure may, if indicative of the situation in vivo, promote vasoconstrictor influences. In addition, because $\mathrm{PGE}_{2}$ is an inhibitor of vascular smooth muscle DNA synthesis (30), a decrease in its production in the PA might have the detrimental effect of inducing the smooth muscle proliferation associated with medial hypertrophy of chronic hypoxia (31).

Endothelial and smooth muscle cell prostacyclin synthesis in response to decreased oxygen concentration has been studied previously in cultured cells (32). Calf pulmonary arterial endothelial, but not smooth muscle cells, were shown to synthesize less prostacyclin in response to low $10 \%$ oxygen. Aortic endothelial cells showed a similar response, but only with $0 \%$ oxygen. Our inability to detect a decrease in endothelial prostacyclin production with $2 \%$ oxygen exposure may mean that fetal, and perhaps early neonatal endothelial cells were relatively adapted to low oxygen in vivo. Species differences may also play a role, although ovine and bovine cells should be closely related. The shorter length of exposure, $1 \mathrm{~h}$ in our studies compared with the $4 \mathrm{~h}$ of others (32) or the earlier passage, 3 compared with 3-15 may also explain the differences.

Mechanism of hypoxia-induced changes in prostaglandin release. The mechanism whereby during hypoxia pulmonary arteries constrict, but systemic arteries and the DA remain dilated is not understood. It could be speculated that, in systemic arteries, endogenous smooth muscle production of prostacyclin and $\mathrm{PGE}_{2}$ maintains dilatation whereas in the PA, the decreased smooth muscle production of dilator prostaglandins promotes contraction. Observations in the isolated lung suggest that, once constriction is initiated, release of prostacyclin, perhaps from endothelial cells, limits the magnitude of the response (33). The mechanism of decreased prostacyclin and $\mathrm{PGE}_{2}$ production in PA smooth muscle cells in response to low oxygen suggests interference with cyclooxygenase or phospholipase $\mathrm{A}_{2}$ activity (34).

Although there is evidence implicating endogenous and bloodborne $\mathrm{PGE}_{2}$ in prenatal patency of the DA (2), the identity of the agent responsible for postnatal closure of the vessel remains unknown, although its formation through a cytochrome P-450 reaction is most likely (3). We have shown, in this study, that DA cells respond to hyperoxia by increased production of prostaglandins, a function observed in whole tissue. The ability to culture and propagate vascular endothelial and smooth muscle cells should provide the opportunity to scale-up production of small quantities of vasoactive substances and to examine important interactions between the two cell types and this, in turn, might improve the prospect of isolating the elusive DA constrictor.

Acknowledgments. The authors thank Dr. Isis Bishai for her assistance with the $\mathrm{PGE}_{2}$ catabolism studies. We also thank Ms. Satti Beharry and Ms. Toni Bothwell for technical assistance, and Ms. Eva Struthers and Mr. Marc Rochon for the illustrations. We also thank Dr. Robert Tibshirani of the Clinical Research Support.

\section{REFERENCES}

1. Gittenberger-de-Groot AC, Strengers JLM, Mentink M, Poelmann RE, Patterson DF 1985 Histologic studies on normal and persistent ductus arteriosus in the dog. J Am Coll Cardiol 6:394-404

2. Coceani F, Olley PM 1986 Eicosanoids and the perinatal circulation: experimental findings and therapeutic prospects. In: Rubatelli FF, Granati B (eds) Neonatal Therapy: An Update. Elsevier, Amsterdam, pp 147-157

3. Coceani F, Breen CA, Lees JG, Falck JR, Olley PM 1988 Further evidence 
implicating a cytochrome P-450-mediated reaction in the contractile tension of the lamb ductus arteriosus. Circ Res 62:471-477

4. Rabinovitch M, Bothwell T, Beharry S, Jackowski G 1988 Qualitative and quantitative differences in protein syntheses comparing fetal lamb ductus arteriosus endothelium and smooth muscle with cells from adjacent vascular sites. Dev Biol 130:250-258

5. Ryan US, Clements E, Habliston D, Ryan JW 1978 Isolation and culture of pulmonary artery endothelial cells. Tissue Cell 10:535-554

6. Ross R 1971 The smooth muscle cell. II. Growth of smooth muscle in culture and formation of elastic fibers. J Cell Biol 50:172-186

7. Rabinovitch M, Bothwell T, Mullen M, Hayakawa B 1988 High-pressure pulsation of central and microvessel pulmonary artery endothelial cells. Am J Physiol 254:C338-C343

8. Ryan US, White LA, Lopez M, Ryan JW 1982 Use of microcarriers to isolate and culture pulmonary microvascular endothelium. Tissue Cell 14:597-606

9. Ryan JW, Chung A, Martin LC, Ryan US 1978 New substrates for radioassay of angiotensin converting enzyme of endothelial cells in culture. Tissue Cell $10: 555-562$

10. Gimbrone MA, Cotran RS 1975 Human vascular smooth muscle in culture: growth and ultrastructure. Lab Invest 33:16-27

11. Tsukada T, Tippens D, Gordon D, Ross R, Gown AM 1987 HHF35, a muscle actin specific monoclonal antibody. Am J Pathol 126:51-60

12. Snedecor GW, Cochran WG 1980 Statistical Methods. Iowa State University Press, Ames, IA

13. Ager A, Gordon JL, Moncada S, Pearson JD, Salmon JA, Trevethick MA 1982 Effects of isolation and culture on prostaglandin synthesis by porcine aortic endothelial and smooth muscle cells. J Cell Physiol 110:9-16

14. Alexander RW, Gimbrone MA 1976 Stimulation of prostaglandin synthesis in cultured human umbilical vein smooth muscle cells. Proc Natl Acad Sci USA 73:1617-1620

15. Pearson JD, Carleton JS, Hutchings A 1983 Prostacyclin release stimulated by thrombin or bradykinin in porcine endothelial cells cultured from aorta and umbilical vein. Thromb Res 29:115-124

16. Bothwell T, Rabinovitch M 1988 A pulmonary artery smooth muscle growth inhibitor released from endothelial cells stretched at high pulsatile pressure. FASEB J 2:A1577

17. Benitz WE, Coulson JD, Lesser DS, Bernfield M 1986 Hypoxia inhibits proliferation of fetal pulmonary arterial smooth-muscle cells in vitro. Pediatr Res 20:966-972

18. Mecham RP, Whitehouse L, Wrenn DS 1987 Smooth muscle-mediated connective tissue remodeling in pulmonary hypertension. Science 237:423-426

19. Stenmark KR, Fasules J, Tucker A, Voelkel NF, Reeves JT 1987 Severe pulmonary arterial hypertension and arterial adventitial changes in newborn calves at $4300 \mathrm{~m}$. J Appl Physiol 62:821-830

20. Ody C, Junod AF 1977 Converting enzyme activity in endothelial cells isolated from pig pulmonary artery and aorta. Am J Physiol 232:C95-98

21. Goldsmith JC, Jafvert BS, Lollar P, Owen WG, Hoak JC 1981 Prostacyclin release from cultured and ex vivo bovine vascular endothelium. Lab Invest 45:191-197

22. Weksler BB, Ley CW, Jaffe EA 1978 Stimulation of endothelial cell prostacyclin production by thrombin, trypsin, and the ionophore A23187. J Clin Invest 62:923-930

23. Funk CD, Powell WS 1985 Release of prostaglandins and monohydroxy and trihydroxy metabolites of linoleic and arachidonic acids by adult and fetal aortae and ductus arteriosus. J Biol Chem 260:7481-7488

24. Forstermann U, Hertting G, Neufang B 1984 The importance of endogenous prostaglandins other than prostacyclin, for the modulation of contractility of some rabbit blood vessels. Br J Pharmacol 81:623-630

25. Coceani F, Huhtanen D, Hamilton NC, Bishai I, Olley PM 1986 Involvement of intramural prostaglandin $\mathrm{E}_{2}$ in prenatal patency of the lamb ductus arteriosus. Can J Physiol Pharmacol 64:737-744

26. Clyman RI, Mauray F, Demers LM, Rudolph AM, Roman C 1980 Does oxygen regulate prostaglandin-induced relaxation in the lamb ductus arteriosus? Prostaglandins 19:489-498

27. Jackson RM, Chandler DB, Fulmer JD 1986 Production of arachidonic acid metabolites by endothelial cells in hyperoxia. J Appl Physiol 61:584-591

28. Rudolph AM 1974 Congenital Diseases of the Heart. Year Book Medical Publishers, Chicago, p 4

29. Tyler T, Leffler C, Wallis R, Cassin S 1975 Effects of prostaglandins of the Eseries on pulmonary and systemic circulations of newborn goats during normoxia and hypoxia. Prostaglandins 10:963-970

30. Owen NE 1985 Prostacyclin can inhibit DNA synthesis in vascular smooth muscle cells. In: Martyn Bailey J (ed) Prostaglandins, Leukotrienes and Lipoxins. Plenum Press, New York, pp 193-204

31. Meyrick B, Reid L 1979 Hypoxia and incorporation of ${ }^{3}[\mathrm{H}]$ thymidine by cells of the rat pulmonary artery and alveolar walls. Am J Pathol 96:51-70

32. Madden MC, Vender RL, Friedman M 1986 Effect of hypoxia on prostacyclin production in cultured pulmonary artery endothelium. Prostaglandins 31:1049-1062

33. Voelkel NF, Gerber JG, McMurtry IF, Nies AS, Reeves JT 1981 Release of vasodilator prostaglandin, $\mathrm{PGI}_{2}$, from isolated rat lung during vasoconstriction. Circ Res 48:207-213

34. Marshall PJ, Kulmacz RJ, Lands WEM 1987 Constraints on prostaglandin biosynthesis in tissues. J Biol Chem 262:3510-3517 